\title{
La Poltrona del Lector
}

\section{Reseñas de algunas publicaciones}

\section{de la Zh.Q.叉}

\section{Por Percy Prado}

\section{Creación artística y psicopatología}

Ramón León (editor)

Lima, 2020

Este libro contiene una selección de conferencias sobre arte psicopatológico dictadas en el contexto de la exposición artística Amentes (2017), que reunía algunas obras pictóricas del museo del hospital psiquiátrico Víctor Larco Herrera (Lima). Se abre con una crónica de los días de conversatorio y detalla lo visto, oído y vivido en la galería del Centro Cultural Ccori Wasi de la Universidad Ricardo Palma durante las conferencias y la muestra artística. Se publican además las contribuciones de importantes psiquiatras e investigadores peruanos y extranjeros como Renato Alarcón, Manuel Ponce, Ramón León, Mauricio Borja-Mostacero y Virgilio Ibarz.

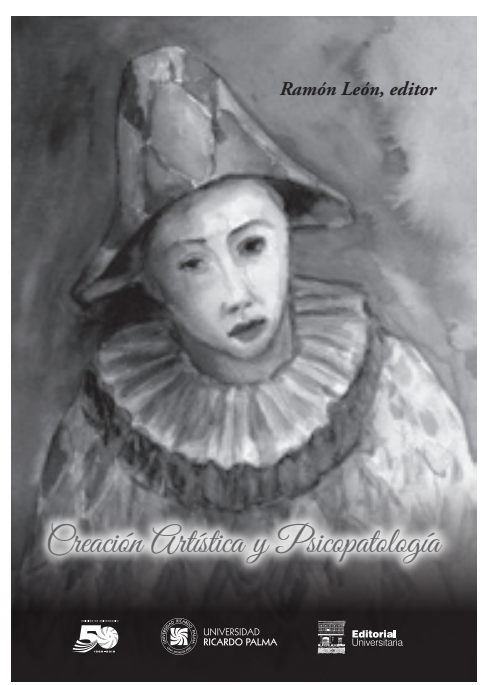

\section{La argumentación lógica del pensamiento natural}

Diógenes Rosales Papa

Lima, 2020

Un texto con el que es posible introducirse en los temas básicos de la lógica moderna. Dirigido a estudiantes universitarios, pero también al alcance de todo público que desee aprender o consolidar aprendizajes sobre el objeto de la lógica: la argumentación. El libro desarrolla, en primer lugar, la lógica informal analizando la argumentación en el lenguaje natural desde las funciones básicas del lenguaje y el uso de las falacias. Luego se analiza también la validez o invalidez de las inferencias aplicando el método de los árboles semánticos y termina con el análisis de los argumentos válidos en la lógica proposicional y cuantificacional.

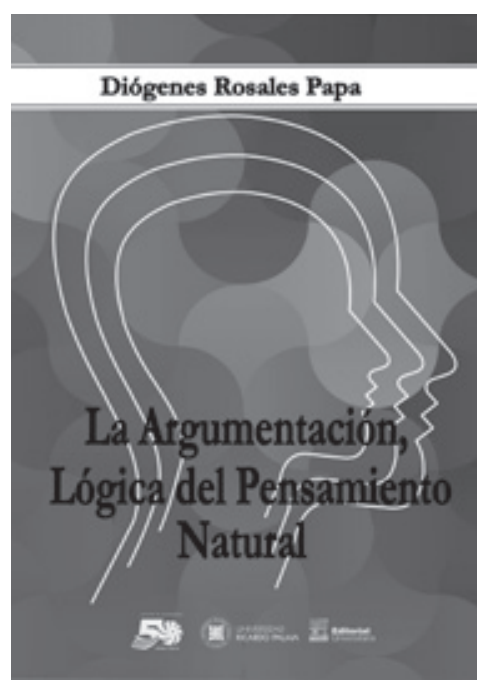



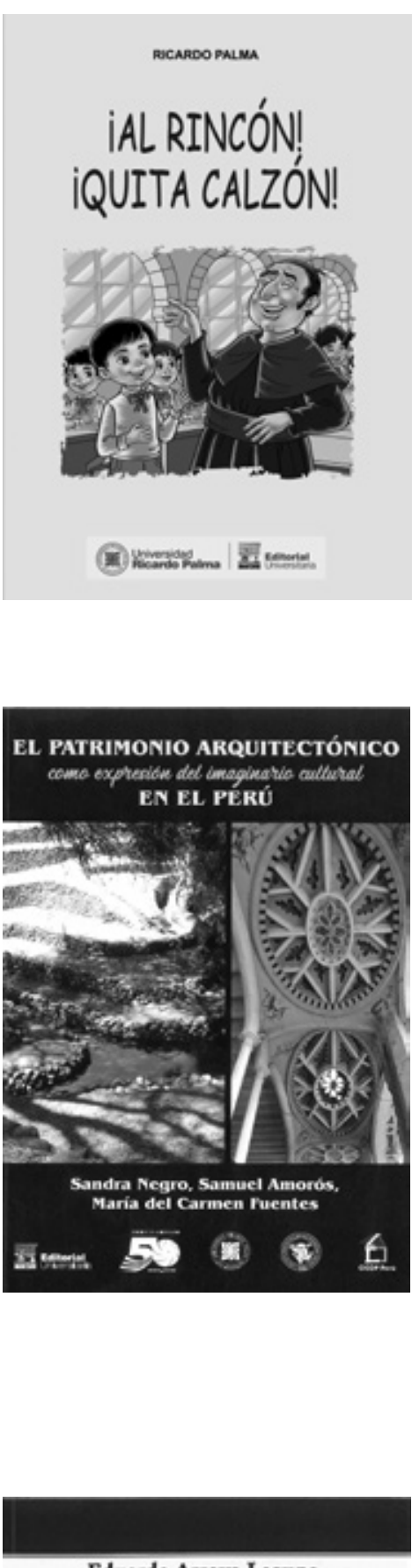

Eduardo Arroyo Laguna

GEOPOLÍTICA INTERNACIONAL

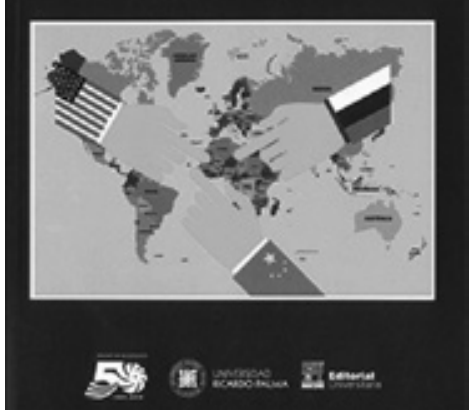

Al rincón quita calzón y Los ratones de fray Martín

Ricardo Palma

Ediciones ilustradas para niños

Lima, 2020

Versiones de dos conocidas y amenas tradiciones dirigidas especialmente a los nińos. Se trata de una novedad editorial que busca acercar a los pequeños lectores a la obra de Ricardo Palma. No solo hallarán entretenimiento en la lectura gracias al acompańamiento de las ilustraciones, sino también aprenderán a reconocer en la obra de Don Ricardo Palma la creatividad de su fértil imaginación, la amenidad de su estilo y, sobre todo, su amor por estas tierras y por los habitantes de ellas.

El patrimonio arquitectónico como expresión del imaginario cultural en el Perú

Sandra Negro, Samuel Amorós, María del Carmen Fuentes (editores) 2019. $313 p p$.

Compila doce investigaciones inéditas en torno a la arquitectura prehispánica, virreinal y republicana temprana. Hay estudios sobre variados monumentos arquitectónicos como los acueductos con galerías filtrantes de Nasca, la iglesia de San Agustín de Saña (siglo XVII), la hacienda Unanue de Cañete, el atrio de la iglesia de Santo Domingo de Arequipa, el Cementerio General de Lima, la iglesia de los Huérfanos de Lima, la capilla de la hacienda Santa María de Maranga y el Panteón de los Próceres. En palabras de nuestro rector, Iván Rodríguez Chávez: «tener y conocer estas investigaciones, no solamente testimonia un pasado de logros y prodigios, sino muestra la capacidad e inteligencia de nuestros arquitectos, artesanos, albañiles y peones, al trazar una continuidad productiva, extendiendo el horizonte de nuestra nación a estadios culturales anteriores a nuestra occidentalización».

\section{Geopolítica internacional}

Eduardo Arroyo Laguna

2019, $150 p p$.

El autor analiza el modelo global neoliberal en el que comprueba la estandarización de un modo de vivir marcado por los hábitos y el uso de un lenguaje común fuertemente ligado a elementos tecnológicos como la informática, la cibernética, la biogenética, entre otros.

Asimismo, muestra cómo en este modelo se desarrollan crisis múltiples (climática, energética, alimenticia, financiera y de valores) que, en cierto modo, evidencian la insuficiencia del sistema y su agotamiento frente a la construcción de una humanidad más avanzada. 
Etnias del Imperio de los incas. Reinos, señoríos, curacazgos y cacicatos

Waldemar Espinoza Soriano

2019, 3 vols., $1930 p p$.

Estudio erudito y riguroso de los grupos sociales y políticos que conformaron el imperio de los incas. Condensa el trabajo de más de 40 años de investigación en el Archivo de Indas y en los archivos nacionales de Perú, Bolivia, Argentina y Ecuador. El autor, uno de los más importantes historiadores peruanos vivos, ha logrado armar el crisol de naciones o etnias existentes durante el Imperio de los incas.

\section{El ciervo en la fuente.}

Ricardo Silva-Santisteban

2019, 2 vols., 1012 pp.

Estos dos volúmenes contienen traducciones de autores como Anacreonte, Catulo, Horacio, Dante, Petrarca, Ariosto, Leopardi, Ungaretti, Quasimodo, Montale, Chaucer, Shakespeare, Villon, Baudelaire, Rimbaud, Poe, Whitman, Wallace Stevens, Goethe, Novalis, Hölderlin, Trakl, entre otros. La fineza de los versos resultado de un trabajo de traducción minucioso destila también la sensibilidad y el pulso poético del autor.

\section{Obra completa y poemas relacionados}

Mateo Rosas de Oquendo

Estudio y edición crítica de Pedro Lasarte 2019. 229 pp.

Uno de los satíricos más significativos del período colonial peruano fue, sin duda, Mateo Rosas de Oquendo (1559?-?). Este volumen compila las sátiras y poemas de un autor del que se conoce muy poco. Su poema más conocido es Sátira [...] a las cosas que pasan en el Pirú, año de 1598, que aparece aquí junto al minucioso estudio crítico y erudito de a figura del autor y de su obra.
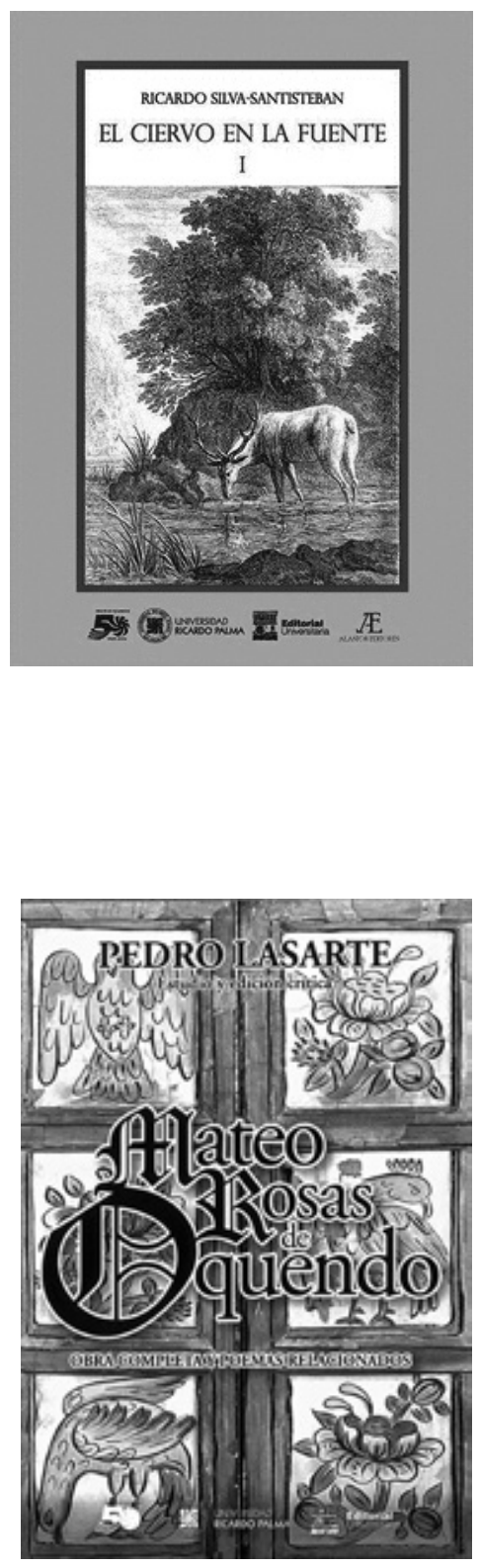

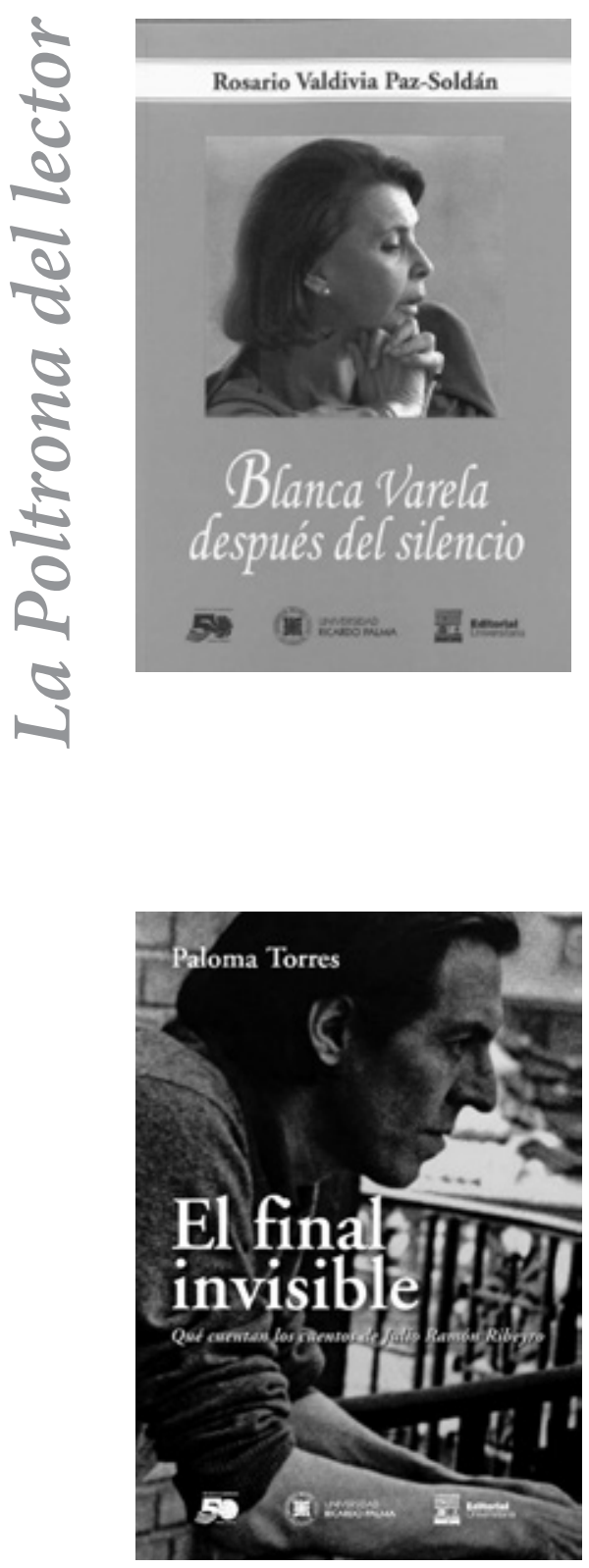

Blanca Varela después del silencio

Rosario Valdivia Paz-Soldán

2019. $168 p p$.

Tras un repaso a la vida de la poeta peruana más célebre de los últimos tiempos, la autora de este estudio crítico nos acerca a la poética valeriana a través de una técnica que reconoce como el silencio de la palabra. Además nos ofrece un minucioso análisis de las nominaciones zoológicas, desde el poemario Ese puerto existe hasta Canto villano y culmina con una bien sustentada propuesta crítica sobre lo no dicho en Canto villano y sobre los conceptos de tiempo, muerte y dios en Ejercicios materiales y El libro de barro.

\section{El final invisible. Qué cuentan los cuentos de Julio Ramón Ribeyro} Paloma Torres

2019. $127 p p$.

En este libro se estudia el final en la cuentística del autor de $L a$ palabra del mudo. Aborda así un aspecto narratológico que no se ha estudiado suficientemente en la literatura en español: el final de la narración. Para ello, la autora recurre al método propuesto por Marco Kunz en su obra El final de la novela. Teoría, técnica y análisis del cierre en la literatura moderna en lengua española (Gredos, 2007). Gracias a un examen original y detallado de los relatos breves de Ribeyro, se comprueba que el cuentista recurre a las mismas estrategias: o se produce un desenlace trágico, o sus finales son aparentemente abiertos o hay una circularidad entre la situación inicial y final del cuento. La autora arriba así a una interesante conclusión: «en los finales de los cuentos de Ribeyro se produce de manera generalizada una toma de conciencia por parte del personaje protagonista», una toma de conciencia «referida exclusivamente al ámbito de la interioridad del personaje, pues no tiene efectos en sus acciones ni repercusiones en el entorno». 